\title{
Valorizar o Brasil para servir à humanidade
}

\author{
José Marques de Melo
}

\section{SciELO Books / SciELO Livros / SciELO Libros}

MELO, JM. Cidadania glocal, identidade nordestina: ética da comunicação na era da internet [online]. Campina Grande: EDUEPB; Latus, 2011. 108 p. ISBN 978-85-63984-07-4. Available from

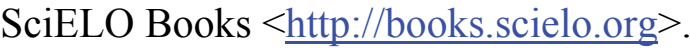

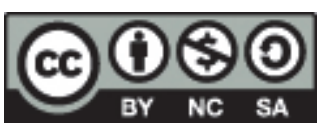

All the contents of this work, except where otherwise noted, is licensed under a Creative Commons Attribution-Non Commercial-ShareAlike 3.0 Unported.

Todo o conteúdo deste trabalho, exceto quando houver ressalva, é publicado sob a licença Creative Commons Atribuição Uso Não Comercial - Partilha nos Mesmos Termos 3.0 Não adaptada.

Todo el contenido de esta obra, excepto donde se indique lo contrario, está bajo licencia de la licencia Creative Commons Reconocimento-NoComercial-CompartirIgual 3.0 Unported. 


\section{Valorizar o Brasil para servir à humanidade ${ }^{7}$}

Aos olhos de visitantes estrangeiros, cujos

claustros acadêmicos festejam séculos de existência, pode parecer precoce a iniciativa de celebrar os 40 anos de uma universidade.

Mas, no Brasil, onde temos sido testemunhas oculares de uma História tão recente quanto enigmática, faz todo sentido comemorar as décadas vencidas.

Como percebeu claramente o sábio potiguar Luis da Câmara Cascudo, trata-se de simbolismo que evidencia a "desesperada vontade de viver" de instituições vitimadas

7 Discurso pronunciado no dia 26 de setembro de 2008, em Mossoró (RN), na solenidade de outorga do título de Doutor Honoris Causa pela Universidade Estadual do Rio Grande do Norte. 
pela castração intelectual durante os primeiros séculos da nossa existência como civilização.

Não podemos esquecer que o Brasil só agora, em 2008, está comemorando o bicentenário da sua imprensa e somente, em 2034, vai celebrar o primeiro centenário da sua universidade.

Vivendo num país que, não obstante os avanços e conquistas do último século, mantém na ignorância vastos contingentes da sua população, sem saber ler, escrever, contar ou argumentar, temos necessidade de festejar ocasionalmente a sobrevivência dos espaços cognitivos e dos projetos culturais.

Vivendo numa sociedade que fomenta a cultura do silêncio, cuja mídia tem sido manietada frequentemente pela incúria da elite política, mais preocupada em pilhar o erário público do que em converter a educação, a ciência e a tecnologia em prioridades nacionais, só nos resta celebrar efemérides como se fossem antídotos para prevenir a síndrome da mordaça.

Vivendo num tempo cuja velocidade implacável produz a sensação de anacronismo material ou de obsolescência espiritual, nada mais oportuno do que fazer uma parada para construir ícones, premiar virtudes, reconhecer méritos. 
E àqueles que generosamente são distinguidos com a benevolência e o carinho desta Universidade só nos resta agradecer a homenagem que nos tributam nesta confraternização acadêmica.

Desejamos que, a cada década, esta Assembleia Universitária volte a se reunir, para festejar êxitos, fortalecer alianças com a sociedade, sinalizar aos mais jovens, com humildade e lealdade, alegria e esperança.

Pois a Universidade tem uma missão irrenunciável, que não se esgota na rotina de ministrar aulas, expedir diplomas, promover congressos, lançar publicações.

Trata-se de dar consequência àquele conjunto de metas que Luis da Câmara Cascudo, melhor do que ninguém, enunciou com tanta clarividência, autoestima, universalidade.

"A Universidade deve valorizar, estudar, defender a Civilização do Brasil. (...) Conhecê-la, amá-la, compreendê-la pela pesquisa ... (...)

Ter o sentimento de solidariedade humana, a compreensão imediata de fatores universais que atuam perto de nós e em nós mesmos. Sentir-se parte do Mundo, não entre os homens, mas com os homens. (...)

Valorizar o Brasil para que possamos ser dignos colaboradores no esforço cultural do Mundo, levando ajuda de nossa competência. 
(...) Não esquecer que somos portadores de uma missão de Cultura. (...)

Não olvidar a universalidade do interesse por tudo que seja humano e ligado à dignidade do Espírito, da Personalidade, Justiça, a Liberdade, o Respeito, o Decoro, a Tranqüilidade Moral. (...)

Assim, a missão universitária, sua alma é preparar os valorizadores da Civilização Brasileira, ampliadores das Culturas, em serviço da Humanidade ". (Fonte: Câmara Cascudo, Luis da - Universidade e Civilização, Natal, Editora Universitária, 1959) 